\title{
The Use of Problem Based Learning Model to Improve Student's Learning Outcomes on Fifth Grade
}

\section{Dyah Kartika Sari}

\author{
SD Negeri Plumbon \\ dyahkartikasari28@gmail.com
}

\section{Article History}

accepted $14 / 11 / 2020$

approved $21 / 11 / 2020$

published 26/11/2020

\begin{abstract}
This study aims to improve learning outcomes of Fifth Grade students of Elementary School in the learning Fourth Theme through the application of the Problem-Based Learning (PBL) model. This was a classroom action research. The study involves Fifth Grade students of the elementary school as the research subject. The data were collected through observation with test and nontest. This research is using two cycles. The results of the study show that: (a) the application of the PBL model is capable of improving the student's outcome (b) In the first cycle, there was five students who passed the grade, that the average value is $62,5 \%$. (c) In the second cycle, there was an improvement for the learning outcomes, that the average value is $75 \%$, which six students passed the grade. (d) the students' learning outcomes after the application of the PBL model namely the number of students who reach the KKM as much as 6 students (75\%) from totally 8 students.
\end{abstract}

Keywords: Problem based learning, learning outcomes, students

\begin{abstract}
Abstrak
Penelitian ini bertujuan untuk meningkatkan hasil belajar siswa kelas 5 sekolah dasar dalam mempelajari tema 4 dengan menggunakan model Problem Based Learning. Ini adalah sebuah Penelitian Tindakan Kelas. Penelitian ini melibatkan siswa kelas 5 sekolah dasar sebagi subjek penelitian. Pengumpulan data dengan menggunakan observasi tes dan non tes. Penelitian ini menggunakan 2 siklus. Hasil dari penelitian ini adalah: (a) Penggunaan model Problem Based Leraning mampu meningkatkan hasil belajar siswa,(b) Dalam siklus pertama, ada 5 siswa yang nilainya tuntas dengan prosentase nilai rata rata sebesar $62,5 \%$.(c)Pada siklus kedua, terdapat peningkatan, dimana jumlah murid yang tuntas nilainya sebanyak 7 orang dengan prosentase rata rata nilai sebesar $87,5 \%$, (d) Hasil belajar siswa setelah menggunakan model problem based learning mengalami peningkatan dengan 7 siswa yang tuntas nilai dari total 8 siswa dengan prosentase $87,5 \%$.
\end{abstract}

Kata kunci: Problem based learning, hasil belajar, siswa

Social, Humanities, and Education Studies (SHEs): Conference Series https://jurnal.uns.ac.id/shes

p-ISSN 2620-9284

e-ISSN 2620-9292 


\section{PENDAHULUAN}

Pembelajaran tematik merupakan pembelajaran dengan mengintegrasikan materi beberapa mata pelajaran dalam satu tema. Pembelajaran tematik memberi peluang untuk lebih menekankan pada pertisipasi atau keterlibatan siswa dalam belajar. Dalam pelaksanaan pembelajaran guru kurang maksimal dalam mengola kelas, belum menggunakan model yang sesuai dengan materi, belum menggunakan media yang menarik bagi siswa, dan hanya menunjukkan keatifan guru, kurang mengaktifkan siswa. Sehingga siswa tidak aktif, kurang antusias, dan siswa cepat bosan dalam mengikuti pembelajaran. Sehingga pembelajaran di kelas menjadi kurang bermakna. Faktor tersebut berdampak pada siswa, yaitu tidak berminat untuk mengikuti pembelajaran dan kurang memahami materi yang diajarkan sehingga berpengaruh pada hasil belajar siswa yang buruk (rendah). Berdasarkan refleksi pembelajaran yang dilakukan selama ini, hasil belajar tematik kelas V SD Negeri Plumbon belum seperti yang diharapkan dilihat dari masih rendahnya hasil belajar siswa. Model pembelajaran berbasis masalah atau dikenal dengan Problem Based Learning (PBL) adalah model pembelajaran yang berpusat pada siswa dimana siswa berupaya menemukan pemecahan masalah dengan menggunakan informasi dari berbagai sumber serta pengalaman sehari- hari

Salah satu strategi pembelajaran yang dapat digunakan untuk memudahkan siswa dalam belajar matematika sekaligus melibatkan siswa aktif dalam pembelajaran yaitu pendekatan Poblem Based Learning. Pendekatan Problem Based Learning adalah pembelajaran yang menggunakan masalah nyata (autentik) yang tidak terstruktur (ill-structured) dan bersifat terbuka sebagai konteks bagi peserta didik untuk mengembangkan keterampilan menyelesaikan masalah dan hasil belajar serta sekaligus membangun pengetahuan baru. (Fathurrohman, 2017:113). Pengertian tersebut mengandung arti bahwa penerapan model Problem Based Learning (PBL) dapat membantu siswa untuk belajar menggunakan konsep apa yang mereka pahami dan mengumpulkan informasi sebanyak-banyaknya. Dalam PBL juga dibutuhkan kerjasama yang kuat antar siswa. Mereka akan bekerjasama dalam mengumpulkan informasi dan menemukan hipotesis permasalahan untuk kemudian secara bersamasama saling menukar informasi untuk mencari jalan keluar dari sebuah permasalahan yang sedang dianalisis.

Berdasararkan kondisi yang telah dipaparkan diatas, salah satu cara untuk meningkatkan hasil belajar pada tema 4 (Sehat Itu Penting ) menggunakan Penelitian Tindakan Kelas (PTK) dengan menggunkan Model Pembelajaran Problem Based Learning (PBL). Menurut Mustamilah (2015:3) Model Pembelajaran Problem Based Learning (PBL) adalah pembelajaran yang memberikan masalah kepada siswa dan siswa diharapkan dapat menyelesaikan masalah yang diberikan dengan pembelajaran yang aktif. Sementara itu, Hamdani (2010: 88) melalui PBL siswa dilibatkan pada kegiatan belajar sehingga pembelajaran yang berlangsung benar benar diserap. Guru hanya fasilitator dan siswa aktif dalam pembelajaran. Dengan demikian peneliti melaksanakan penelirian tindakan dengan Model Pembelajaran Problem Based Learning (PBL) diharapkan mampu meningkatkan hasil belajar siswa kelas 5 SD Negeri Plumbon

\section{METODE}

Metode penelitian pada dasarnya merupakan cara ilmiah untuk mendapatkan data. Data yang diperoleh melalui penelitia $n$ itu adalah data teramati yang mempunyai kriteria tertentu yaitu valid (Sugiyono, 2013:02). Jenis penelitian yang digunakan merupakan Penelitian Tindakan Kelas (PTK). Subyek pada penelitian ini adalah peserta didik kelas 5 di salah satu SD Negeri Plumbon dengan jumlah 8 siswa. Rancangan penelitian yang digunakan pada penelitian ini adalah model yang dikemukakan oleh Kemmis \& MC Taggart yang setiap siklus terdiri dari 3 
tahapan yaitu perencanaan, pelaksanaan dan observasi, serta refleksi. Teknik pengumpulan data di dalam penelitian ini berupa tes dan non tes. Dalam siklus pertama, diujikan 10 soal dengan total nilai benar adalah 100.Sedangkan pada siklus kedua, soal yang diberikan sama dengan siklus sebelumnya sebnayak 10 soal dengan total nilai benar. Observasi dengan menggunakan non test yaitu dengan mengamati kehadiran dan keaktifan siswa dalam proses pembelajaran.

\section{HASIL DAN PEMBAHASAN}

Pada bagian ini, memaparkan hasil analisis dan data penelitian tentang hasil belajar muatan PPKn dan muatan IPS pada kelas 5 di salah satu SD Negeri Salatiga dengan menggunakan model pembelajaran Problem Based Learning (PBL). Peningkatan aktivitas guru dan siswa dapat dilihat pada tabel dibawah ini:

Tabel 1. Rata-rata Skor Observasi Keaktifan siswa

\begin{tabular}{llll}
\hline Aspek & \multicolumn{3}{l}{ Skor Rata-rata } \\
\hline Keaktifan siswa & prasiklus & Siklus & Siklus \\
& & 1 & 2 \\
Kehadiran & 0.50 & 0.62 & 0.87 \\
Pemahaman & 0.50 & 0.62 & 0.87
\end{tabular}

Berdasarkan tabel di atas perbandingan rata-rata skor observasi akeaktifan siswa dapat diketahui mengalami peningkatan. Setelah melaksanakan siklus I mengalami peningkatan pada aktivitas siswa sebesar $0,12 \%$. Pada siklus II persentase aktivitas mengalami peningkatan sebesar $0,25 \%$, total keseluruhan peningkatan aktivitas siswa sebesar $0,37 \%$. berikut :

Sedangkan untuk peningkatan hasil belajar siswa dapat dilihat pada tabel 2

Tabel 2 perbandingan ketuntasan hasil belajar siswa

\begin{tabular}{llll}
\hline \multicolumn{1}{c}{ Aspek } & & \multicolumn{2}{c}{ Skor Rata-rata } \\
\hline Ketuntasan nilai & prasiklus & Siklus 1 & Siklus 2 \\
Siswa Tuntas & 50 & 62.50 & 87.50 \\
Siswa Tidak Tuntas & 50 & 37.50 & 25.00 \\
& & & \\
\hline
\end{tabular}

Berdasarkan tabel 2 perbandingan ketuntasan hasil belajar siswa pada tema 4 dapat diketahui terdapat peningkatan hasil belajar dari prasiklus, siklus I, dan siklus II. Pada kondisi awal atau prasiklus terdapat 4 siswa yang tuntas belajar dan 4 siswa tidak tuntas belajar. Pada siklus 1, ketuntasan siswa meningkat dari 4 siswa ke 5 siswa. Pada siklus 2, terdapat peningkatan jumlah siswa yang tuntas nilai sebanyak 7 siswa ( $87.5 \%$ ) dari 8 siswa keseluruhan

Model Problem Based Learning (PBL) membuat siswa dapat lebih aktif berpartisipasi dalam proses pembelajaran yang sedang berlangsung, siswa mendapatkan pengalaman untuk memecahkan masalah serta mencari solusi dari masalah tersebut, siswa menjadi lebih bertanggung jawab pada proses pembelajaran berlangsung. Karena pada penerapan model pembelajaran Problem Based Learning (PBL) siswa memecahkan masalah yang terjadi nyata dikehidupan sehari-hari, ini berdampak pada keaktifan siswa yang ingin mencari tahu jawabannya. Hal ini perkuat oelh penelitian yang dilakukan oleh Monika 
Setyaningrum ( 2018: 1) yang berjudul "Peningkatan hasil belajar menggunakan model problem based learning ( $\mathrm{PBL}$ ) pada siswa kelas 5 SD".Pembelajaran dengan menggunakan model Problem Based Learning dapat meningkatkan hasil belajar terutama pada muatan pelajaran PPKn dan IPS pada tema 1 subtema 1 siswa kelas 5 SD Negeri Salatiga.

Berdasarkan paparan di atas, maka peneliti ini telah memberikan sumbangan ilmu yaitu penggunaan model pembelajaran Problem Based Learning (PBL) dengan beberapa tahap yaitu orientasi peserta didik pada masalah, mengorganisasikan peserta didik, membimbing penyelidikan baik individu maupun kelompok, mengembangkan dan menyajikan hasil karya, serta menganalisa dan mengevaluasi proses pemecahan masalah.

\section{SIMPULAN}

Berdasarkan hasil penelitian dan pembahasan dapat disimpulkan bahwa penggunaan model pembelajaran Problem Based Learning (PBL)pada pembelajaran tema Sehat Itu Penting dapat meningkatkan hasil belajar dan aktivitas siswa. Peningkatan hasil belajar sebesar $12,5 \%$ pada Siklus I dan $25 \%$ pada Siklus II. Observasi aktivitas siswa mengalami peningkatan, pada Siklus I hanya sebesar $12 \%$ dan meningkat menjadi $25 \%$ pada Siklus II. Dengan demikian hal ini membuktikan bahwa penerapan model pembelajaran Problem Based Learning (PBL) dapat meningkatkan hasil belajar terutama pada tema 4 Sehat Itu Penting pada siswa kelas 5 SD Negeri Plumbon.

Bagi guru setelah melaksanakan penelitian diharapkan mampu mengembangkan kompetensi dan pengetahuan dengan mengaplikasikan penggunaan model Problem Based Larning di dalam proses pembelajaran. Bagi siswa dengan adanya penerapan model pembelajaran Problem Based Learning (PBL) siswa diharapakan akan lebih aktif berpartisipasi dalam proses pembelajaran, mempunyai rasa tanggung jawab dan kepercayaan diri yang tinggi dalam berkelompok. Dengan demikian hasil belajar akan meningkat.

\section{DAFTAR PUSTAKA}

Fathurrohman, M. (2017). Model-Model Pembelajaran Inovatif. Jogjakarta, Indonesia: ArRuzz Media

Hamdani. 2010. Strategi Belajar Mengajar. Bandung: Pustaka Setia

Mustamilah. (2015). Peningkatan Keterampilan Proses Pemecahan masalah dan Hasil Belajar Mengguanakan Model Problem Based LearningPada Sub Tema Merawat Tubuhku Siswa Kelas 1 SD Negeri 1 Gosono-Wonosegoro. Scholaria, 5 (1) 3

Setyaningrum, Monika.( 2018 ). Peningkatan hasil belajar menggunakan model problem based learning (PBL) pada siswa kelas 5 SD.Jurnal Riset Teknologi dan Pendidikan Volume 1. Mataram

Sugiyono. (2013). Metode Penelitian Kuantitatif,kualitatif dan R \& D. Bandung, Indonesia: Alfabeta. 